\title{
Comparison between sterilized zeolite and natural zeolite in the Cactus Pear (Opuntia Ficus-Indica L. Mill.) growing
}

\author{
Domenico Prisa* \\ CREA Research Centre for Vegetable and Ornamental Crops, Council for Agricultural Research and Economics, Via dei \\ Fiori 8, 51012 Pescia, PT, Italy.
}

Publication history: Received on 20 September 2020; revised on 27 September 2020; accepted on 29 September 2020

Article DOI: https://doi.org/10.30574/gscarr.2020.5.1.0080

\begin{abstract}
In this experiment it was determined whether the capacities of zeolites are influenced by the microbial colonies that are present in the soil, which can with their activity increase the interactions between roots, zeolites and soil. The microorganisms have the ability to lower the $\mathrm{pH}$ of the substrate and soil and can determine a solubilization of the mineral elements contained, which are more absorbed by plants. The experimental groups were: i) group without zeolites, irrigated with water and substrate previously fertilized; ii) group with natural chabazite and fertilised substrate; iii) group with sterilized chabazite and fertilised substrate. The zeolite was sterilized at high pressure saturated steam at $121^{\circ} \mathrm{C}$ for about 20 minutes. The theses treated with natural chabazite showed an improvement of all agronomic parameters analyzed on Opuntia ficus-indica plants, fruit characteristics and mineral content in the three cultivars Sulfarina, Sanguigna and Muscaredda. Natural chabazite gave better results than sterilized chabazite and untreated control, demonstrating that indeed the presence of the biotic component of zeolite plays a fundamental role in the interactions between zeolite and plant. All these aspects are very important for growers because the use of zeolites, especially natural chabazite, guarantees the possibility to reduce the amount of fertilizers in the substrates and to optimize irrigation while obtaining quality plants that grow better, produce more and suffer less.
\end{abstract}

Keywords: Opuntia ficus-indica; Microorganisms; Sustainable agriculture; Zeolites; Rhizosphere

\section{Introduction}

Opuntia ficus-indica L. Mill. is one of the main species of the genus Opuntia, plants belonging to the cactaceae family, native to the Americas, where they are widespread in arid tropical and subtropical zones. The prickly pear grows now spontaneous in the whole Mediterranean basin, Italy included, and is the only naturalized Opuntia in Europe. Opuntias have a rare peculiarity in the plant kingdom: not only do they have edible flowers and fruits, but part of the stem can also be eaten. For this reason and for the extraordinary ability to grow luxuriant in some of the most hostile habitats on earth, opuntias have been a staple food of the diet of the native populations of the Southwest of the United States, of those who later settled in Central and South America, as well as of the inhabitants of some areas of Europe and the Middle East [1]. In the cactaceae family, Opuntia is the genus richest in sub-genres, varieties and shapes, sizes, colors and is the one that grows most easily because the plants do not need to be cultivated or irrigated and resist the harshest climate changes [2]. The two main branches of the genus Opuntia are Platyopuntia, to which the prickly pear belongs, and Cylindropuntia. The main difference between the two families of Opuntia is the way the stems are structured: the Platyopuntia, to support the shovels, develop a network of fibers that can be easily cut; the Cylindropuntia, on the other hand, branch out, inside them, in a woody stem that is very difficult to cut. Another difference is the goodness of the

\footnotetext{
${ }^{*}$ Corresponding author: Domenico Prisa

CREA Research Centre for Vegetable and Ornamental Crops, Council for Agricultural Research and Economics, Via dei Fiori 8, 51012 Pescia, PT, Italy..
} 
fruit: the fruit of Platyopuntia is a delicacy with a taste very similar to watermelon, even if more pulpy and dotted with small black seeds; the fruit of Cylindropuntia, instead, has such a bad taste to be inedible [3,4]. A further difference between these two families concerns what is inside the shovels: by practicing a light pressure on the trunk of Platyopuntia you can extract a bitter and sticky juice that you can drink in times of emergency, but above all use for its medicinal properties; on the contrary, Cylindropuntia have a hard trunk without mucilage. The opuntia cladodes are a storehouse of nutrients: they contain a good amount of mineral salts and amino acids.Vegetarians can find in the cladodes (nopales) a source of high quality protein. The fruits of Opuntia have also undergone careful research that has shown positive correlations between their consumption and the decrease in blood glucose levels. While the yellow, orange or pink flowers contain active substances rich in curative properties, especially flavonoids. The petals of the Opuntia flower are collected, dried and sold in bulk or in sachets, in the form of capsules or liquid extract [5,6].

Natural Zeolites are a mineral family composed by 54 different species chemically defined as "hydrated alluminosilicates of alkaline and alkaline earth elements" and structurally belonging to the tectosilicates. Due to their crystal chemistry, zeolites show physical-chemical peculiarities such as high and selective cation exchange capacity (CEC), reversible dehydration, selective molecular absorption, and catalytic behaviour. Therefore, rocks containing more than $50 \%$ of zeolites (zeolitites) are widely and profitably utilized in the purification of municipal, zootechnical and industrial wastewaters, as additive in animal nutrition, agriculture and floriculture [7,8]. Commercial use of natural zeolites is still in its infancy, but more than 300,000 tons of zeolite-rich tuff is extracted annually in the United States, Japan, Bulgaria, Hungary, Italy, Yugoslavia, Korea, Mexico, Germany, and the Soviet Union [9,10]. Natural zeolites have found applications as fillers in the paper industry, as light aggregates in construction, cement and concrete, as ion exchangers in water purification and municipal effluent purification, as traps for radioactive species in wastewater from nuclear plants, in oxygen production, as catalysts for oil fields, as acid-resistant absorbents and in the drying and purification of natural gas $[11,12]$. The pronounced selectivity of zeolite for large cations, such as ammonium and potassium, has also been exploited in the preparation of chemical fertilizers that improve the capacity of retention of nutrients in soils promoting a slower release of these elements for absorption by plants, in rice fields, where losses by runoff of $50 \%$ of nitrogen supplied are frequent $[13,14]$. The article presents the results of a research that wants to highlight the microbial component of zeolites, of particular and fundamental importance in the interactions that take place in the rhizosphere between the roots of plants and this mineral of volcanic origin.
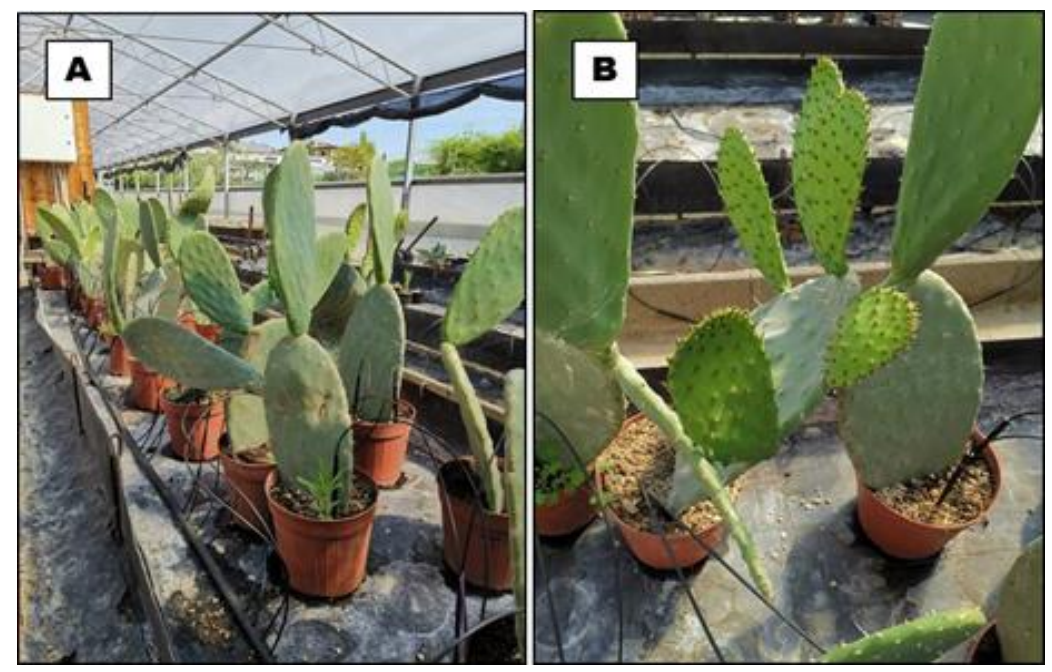

Figure 1 Particular of Opuntia ficus-indica in greenhouse cultivation (A) and the formation of new cladodes on plants grown with zeolite substrate (B).

\section{Material and methods}

The experiments, started in January 2019, were conducted in the greenhouses of CREA-OF in Pescia (Pt), Tuscany, Italy $\left(43^{\circ} 54^{\prime} \mathrm{N} 10^{\circ} 41^{\prime} \mathrm{E}\right)$ on Opuntia ficus-indica (Figure 1A,1B) cvs yellow "Sulfarina", red "Sanguigna", white "Muscaredda".

The plants were placed in $\varnothing 24 \mathrm{~cm}$ pots; 30 plants per thesis, divided into 3 replicas of 10 plants each. All plants were fertilized with a controlled release fertilizer $\left(3 \mathrm{~kg} \mathrm{~m}^{-3}\right.$ Osmocote Pro®, 9-12 months with $190 \mathrm{~g} / \mathrm{kg} \mathrm{N}, 39 \mathrm{~g} / \mathrm{kg} \mathrm{P,} 83 \mathrm{~g} / \mathrm{kg}$ $\mathrm{K})$ mixed with the growing medium before transplanting. After a year the plants were transplanted into a 24-diameter pot and fertilized again. The part of the substrate that was missing in the pot was re-potted. 
The experimental groups were:

- $\quad$ group without zeolites (CTRL) (peat 100\%), irrigated with water and substrate previously fertilized;

- group with natural chabazite (CN) (peat 80\% + chabazite 20\%) and fertilised substrate;

- group with sterilized chabazite (CS) (peat 80\% + chabazite 20\%) and fertilised substrate. The zeolite was sterilized at high pressure saturated steam at $121^{\circ} \mathrm{C}$ for about 20 minutes.

The chabazitic- zeolites had the following characteristics: 1) qualitative-quantitative mineralogical analysis (\% by weight with standard deviations in brackets) carried out by X-ray powder diffractogram according to the RIETVELDRIR methodology [12]: chabazite 66.2 (1.0); phillipsite 2.4 (0.5); mica 5.6 (0.6); K-feldspar 10.3 (0.8); pyroxen 2.2 (0.5); volcanic glass 13.3 (1.5); 2) Total zeolithic content (\%): 68.6 (1.3), of which 66.2 due to chabazite and 2.4 from phillipsite. Cation exchange capacity (in meq/g with standard deviation in brackets) determined using the methodology described in Gualtieri et al. (1999) [15]: 2.15 (0.15) of which 1.42 due to $\mathrm{Ca}, 0.04$ to $\mathrm{Mg}, 0.05$ to $\mathrm{Na}$ and 0.64 to $\mathrm{K}$. The natural chabazite had a microbial count of $3 \times 10^{6} \mathrm{ufc} / \mathrm{g}$ of zeolites. While sterilized zeolite showed no bacterial colonies.

The $\mathrm{pH}$ of the zeolite was 6.9. For the experimentation of plant growth was used $\varnothing 3-6 \mathrm{~mm}$.

The plants were watered 1 times a week and grown for 21 months. The plants were irrigated with drip irrigation. The irrigation was activated by a timer whose program was adjusted weekly according to climatic conditions and the fraction of leaching. On September 3, 2020, plant height, vegetative weight, roots weight, cladodes number, fruits number, lenght and weight, peel and pulp weight, seeds weight. In addition, the content of nitrogen, potassium, phosphorus, calcium, magnesium, iron in fruit tissues was analyzed (Jenway 6305016300 visible spectrophotometer).

\subsection{Statistics}

The experiment was carried out in a randomized complete block design. Collected data were analysed by one-way ANOVA, using GLM univariate procedure, to assess significant $(P \leq 0.05,0.01$ and 0.001$)$ differences among treatments. Mean values were then separated by LSD multiple-range test $(P=0.05)$. Statistics and graphics were supported by the programs Costat (version 6.451) and Excel (Office 2010).

\section{Results}

The test showed a significant improvement of agronomic parameters analyzed on Opuntia ficus-indica plants, fruit growth and mineral content in the three varieties, Sulfarina, Muscaredda and Sanguigna. In general, the higher quality increase of plants and fruits can be seen in the thesis treated with natural chabazite compared to sterilized chabazite and untreated control. In particular, plants treated with natural chabazite have shown a significant increase in plant height, vegetative and root weight and number of new cladodes compared to sterilized zeolite and control. In addition, the same thesis (CN) showed an increase in fruit quality in terms of number of fruits, fruit length and weight, peel, pulp and seed weight. There was also an increase in the mineral content of fruits grown on natural zeolite (CN), compared to sterilized zeolite (CS) and control (CT).

In (Table 1), in Sulfarina there was a significant increase in plant height in (CN) with $79.18 \mathrm{~cm}$ compared to $72.76 \mathrm{~cm}$ of (CS) and $67.70 \mathrm{~cm}$ of untreated control. Furthermore there was a significant increase in the vegetative weight $1.59 \mathrm{~kg}$ $(\mathrm{CN}), 0.96 \mathrm{~kg}$ in (CS) and $0.80 \mathrm{in}(\mathrm{CT})$. Same trend for the root weight where (CN) showed a weight of $0.75 \mathrm{~kg}$, (CS) of $0.65 \mathrm{~kg}$ and the untreated control of $0.48 \mathrm{~kg}$. Also for the number of new cladodes, the treatment with (CN) was the optimal with 5.40 , compared to 3.40 of (CS) and 2.20 of the control.

In Sanguigna (Table 1), there was a significant increase in plant height in (CN) with $76.46 \mathrm{~cm}$ compared to $70.94 \mathrm{~cm}$ of (CS) and $66.50 \mathrm{~cm}$ of untreated control. A significant increase in the vegetative weight $1.20 \mathrm{~kg}(\mathrm{CN}), 0.82 \mathrm{~kg}$ in (CS) and 0.74 in (CT). Similarly for the root weight where (CN) showed a weight of $0.74 \mathrm{~kg}$, (CS) of $0.65 \mathrm{~kg}$ and the untreated control of $0.50 \mathrm{~kg}$. Also for the number of new cladodes the treatment with (CN) was the most performing with 5.40 , compared to 4.00 of (CS) and 3.20 of the control (Figure 2).

In Muscaredda (Table 1) there was a significant increase in plant height in (CN) with $85.64 \mathrm{~cm}$ compared to $81.46 \mathrm{~cm}$ of (CS) and $76.62 \mathrm{~cm}$ of untreated control. In addition a significant increase in vegetative weight $2.02 \mathrm{~kg}$ (CN), $1.72 \mathrm{~kg}$ in (CS) and 1.26 in (CT). Identical trend for the root weight where (CN) showed a weight of $0.95 \mathrm{~kg}$, (CS) of $0.80 \mathrm{~kg}$ and 
the untreated control of $0.62 \mathrm{~kg}$ (Figure 3). Even for the number of new cladodes the treatment with (CN) was the most efficient with 5.60 , compared to 4.20 of (CS) and 3.40 of the control.

Table 1 Evaluation of the zeolite use on the agronomic characters of Opuntia ficus-indica

\begin{tabular}{|c|c|c|c|c|c|}
\hline $\begin{array}{l}\text { Opuntia } \\
\text { cultivar }\end{array}$ & Groups & $\begin{array}{c}\text { Plant } \\
\text { height } \\
\text { (cm/plant) }\end{array}$ & $\begin{array}{c}\text { Vegetative } \\
\text { weight } \\
\text { (kg/plant) }\end{array}$ & $\begin{array}{c}\text { Roots } \\
\text { weight } \\
\text { (Kg/plant) }\end{array}$ & $\begin{array}{c}\text { Pads } \\
\text { number } \\
\text { (nºlant) }\end{array}$ \\
\hline \multirow{4}{*}{ Sulfarina } & $\mathrm{CT}$ & $67,60^{c}$ & $0,80^{c}$ & $0,48^{c}$ & $2,20^{c}$ \\
\hline & $\mathrm{CN}$ & $79,18^{\text {a }}$ & 1,59 a & $0,75^{\text {a }}$ & $5,40^{\text {a }}$ \\
\hline & $\mathrm{CS}$ & $72,76^{\mathrm{b}}$ & $0,96^{\mathrm{b}}$ & 0,65 b & $3,40 \mathrm{~b}$ \\
\hline & ANOVA & $* * *$ & $* * *$ & $* * *$ & $* * *$ \\
\hline \multirow{4}{*}{ Sanguigna } & $\mathrm{CT}$ & $66,50^{c}$ & $0,74^{c}$ & $0,50^{c}$ & $3,20^{c}$ \\
\hline & $\mathrm{CN}$ & $76,46^{\mathrm{a}}$ & $1,20^{\mathrm{a}}$ & $0,74^{\mathrm{a}}$ & 5,40 a \\
\hline & $\mathrm{CS}$ & $70.94 \mathrm{~b}$ & $0,82^{\mathrm{b}}$ & $0,65^{b}$ & $4,00^{\mathrm{b}}$ \\
\hline & ANOVA & $* * *$ & $* * *$ & $* * *$ & $* * *$ \\
\hline \multirow{4}{*}{ Muscaredda } & $\mathrm{CT}$ & $76,62^{c}$ & $1,26^{c}$ & $0,62^{c}$ & $3,40^{c}$ \\
\hline & $\mathrm{CN}$ & $85,64^{a}$ & $2,02^{\mathrm{a}}$ & $0,95^{\text {a }}$ & $5,60^{\text {a }}$ \\
\hline & $\mathrm{CS}$ & $81,46^{b}$ & $1,72^{b}$ & $0,80^{\mathrm{b}}$ & $4,20^{\mathrm{b}}$ \\
\hline & ANOVA & $* * *$ & $* * *$ & $* * *$ & $* * *$ \\
\hline
\end{tabular}

One-way ANOVA; n.s. - non significant; ${ }^{* * *}, * * *$ - significant at $\mathrm{P} \leq 0.05,0.01$ and 0.001 , respectively; different letters for the same element indicate significant differences according to Tukey's (HSD) multiple-range test $(\mathrm{P}=0.05)$. Legend: $(\mathrm{CT})$ control; $(\mathrm{CN})$ natural zeolite ; $(\mathrm{CS})$ sterilized zeolite

In Table 2 (fruits quality), in the Sulfarina variety there was a significant increase in the number of fruits in (CN) 7.00 , succeeded by 4.80 of (CS) and 4.20 of the untreated control. A significant increase of the length of the fruit in the thesis (CN) with $9.56 \mathrm{~cm}$, while $7.42 \mathrm{~cm}$ in (CS) and $6.29 \mathrm{~cm}$ in (CT). It was noted a greater weight of the fruit in (CN) with $135.02 \mathrm{~g}$, compared to $129.70 \mathrm{~g}$ of (CS) and $123.32 \mathrm{~g}$ of the control. Also for the peel weight the treatment (CN) was the best with $52.46 \mathrm{~g}$, same for the pulp weight with $78.70 \mathrm{~g}$. As for the weight of the seeds, the treatments (CN) and (CS) were similar and better than the untreated control, with $3.90 \mathrm{~g}, 3.92 \mathrm{~g}$ and $3.40 \mathrm{~g}$ respectively.

Table 2 Evaluation of the zeolite use on the fruits quality characters of Opuntia ficus-indica

\begin{tabular}{|c|c|c|c|c|c|c|c|}
\hline $\begin{array}{l}\text { Opuntia } \\
\text { cultivar }\end{array}$ & Groups & $\begin{array}{c}\text { Fruit } \\
\text { number } \\
\left(n^{\circ} / \text { plant }\right)\end{array}$ & $\begin{array}{c}\text { Fruit } \\
\text { lenght } \\
\text { (cm/fruit) }\end{array}$ & $\begin{array}{c}\text { Fruit } \\
\text { weight } \\
\text { (g/fruit) }\end{array}$ & $\begin{array}{c}\text { Peel } \\
\text { weight } \\
\text { (g/fruit) }\end{array}$ & $\begin{array}{c}\text { Pulp } \\
\text { weight } \\
\text { (g/fruit) }\end{array}$ & $\begin{array}{c}\text { Seed } \\
\text { weight } \\
\text { (g/fruit) }\end{array}$ \\
\hline \multirow{4}{*}{ Sulfarina } & $\mathrm{CT}$ & $4,20^{b}$ & $6,29 c$ & $123,32^{c}$ & $46,30^{c}$ & $72,84^{c}$ & $3,40^{b}$ \\
\hline & $\mathrm{CN}$ & $7,00^{\text {a }}$ & $9,56^{\text {a }}$ & $135,02^{\text {a }}$ & $52,46^{\mathrm{a}}$ & 78,70 a & $3,90^{\text {a }}$ \\
\hline & $\mathrm{CS}$ & $4,80^{b}$ & $7,42 \mathrm{~b}$ & $129,70^{\mathrm{b}}$ & $48,44 \mathrm{~b}$ & 75,22 b & $3,92^{a}$ \\
\hline & ANOVA & $* * *$ & $* * *$ & $* * *$ & $* * *$ & $* * *$ & $*$ \\
\hline \multirow{4}{*}{ Sanguigna } & $\mathrm{CT}$ & $5,21^{c}$ & $10,78^{b}$ & $132,78^{b}$ & $58,36^{c}$ & $68,00^{c}$ & $3,20 \mathrm{~b}$ \\
\hline & $\mathrm{CN}$ & $7,20^{\text {a }}$ & $12,82^{\mathrm{a}}$ & $137,72^{\text {a }}$ & $62,98^{\mathrm{a}}$ & $73,96^{\mathrm{a}}$ & 3,80 ab \\
\hline & $\mathrm{CS}$ & $6,20 \mathrm{~b}$ & $10,96^{b}$ & $134,59 \mathrm{~b}$ & 59,30 b & $71,20 \mathrm{~b}$ & $4,20^{\mathrm{a}}$ \\
\hline & ANOVA & $* * *$ & $* * *$ & $* * *$ & $* * *$ & $* * *$ & $*$ \\
\hline \multirow{4}{*}{ Muscaredda } & $\mathrm{CT}$ & $5,00^{c}$ & $7,58^{c}$ & $121,86^{b}$ & $53,20^{c}$ & $61,78^{c}$ & $3,40^{b}$ \\
\hline & $\mathrm{CN}$ & $7,20^{\text {a }}$ & $8,78^{a}$ & $128,24^{\mathrm{a}}$ & $58,80^{\text {a }}$ & $69,06^{a}$ & $4,20^{\text {a }}$ \\
\hline & $\mathrm{CS}$ & $6,20^{b}$ & 7,87 b & 125,68 a & $54,86^{\text {b }}$ & $63,18^{b}$ & $3,40^{b}$ \\
\hline & ANOVA & $* * *$ & $* * *$ & $* * *$ & $* * *$ & $* * *$ & $*$ \\
\hline
\end{tabular}

One-way ANOVA; n.s. - non significant; *,*,*** - significant at P $\leq 0.05,0.01$ and 0.001 , respectively; different letters for the same element indicate significant differences according to Tukey's (HSD) multiple-range test $(P=0.05)$. Legend: $(\mathrm{CT})$ control; $(\mathrm{CN})$ natural zeolite ; $(\mathrm{CS})$ sterilized zeolite 
In the Sanguigna variety (Table 2), a significant increase in the fruits number in (CN) 7.20, replaced by 6.20 of (CS) and 5.21 of the untreated control. It was observed a significant increase of the fruit lenght in (CN) with $12.82 \mathrm{~cm}$, while 10.96 $\mathrm{cm}$ in (CS) and $10.78 \mathrm{~cm}$ (CT). A remarkable increase in the fruit weight in (CN) with $137.72 \mathrm{~g}$, compared to $134.59 \mathrm{~g}$ of (CS) and $132.78 \mathrm{~g}$ of the control. Concerning the peel weight the treatment (CN) was also the best with $62.98 \mathrm{~g}$, the same for the pulp weight with $73.96 \mathrm{~g}$. Regarding the seeds weight only the treatment (CS) with $4.20 \mathrm{~g}$ was better than the untreated control (CT) with $3.20 \mathrm{~g}$.

In the Muscaredda variety (Table 2) was revealed a significant increase in the number of fruits in (CN) 7.20 , followed by 6.20 of (CS) and 5.00 of the untreated control. A sensible increase of the length of the fruit in the thesis (CN) with $8.78 \mathrm{~cm}$, while $7.87 \mathrm{~cm}$ in (CS) and $7.58 \mathrm{~cm}$ in (CT). An increased weight of the fruit in (CN) and (CS) with $128.24 \mathrm{~g}$ and $125.68 \mathrm{~g}$, compared to $121.86 \mathrm{~g}$ of the control. For the peel weight the treatment (CN) was also the best with $58.80 \mathrm{~g}$, the same for the flesh weight with $69.06 \mathrm{~g}$. Regarding the weight of the seeds, the treatment (CN) was the most efficient with $4.20 \mathrm{~g}$.

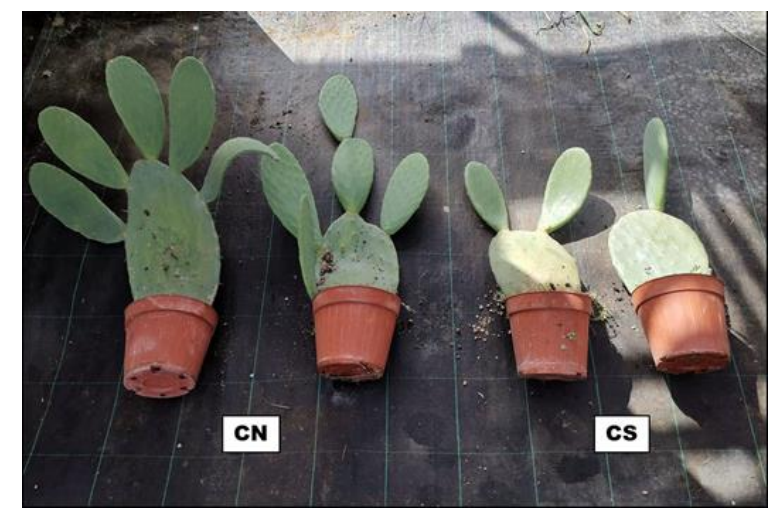

Figure 2 Comparison between natural zeolite (CN) and sterilized zeolite (CS) on growth of Opuntia ficus-indica cv 'Sanguigna'

In (Table 3) (mineral content of the fruits), in the Sulfarina cultivar there was an increase in the mineral content of $\mathrm{N}, \mathrm{P}, \mathrm{K}, \mathrm{Ca}, \mathrm{Mg}$ and Fe for the treatment (CN), higher than both (CS) and the untreated control. The same improvement was also found in the Sanguigna and Muscaredda varieties.

Table 3 Evaluation of the zeolite use on the mineral contents of Opuntia ficus-indica fruits

\begin{tabular}{|c|c|c|c|c|c|c|c|}
\hline $\begin{array}{l}\text { Opuntia } \\
\text { cultivar }\end{array}$ & Groups & $\begin{array}{c}\text { N-content } \\
\text { (mg g-1 } \\
\text { DW) }\end{array}$ & $\begin{array}{c}\text { P-content } \\
\left(\mathrm{mg} \mathrm{g}^{-1}\right. \\
\text { DW) }\end{array}$ & $\begin{array}{c}\text { K-content } \\
\text { ( } \text { mg g }^{-1} \\
\text { DW) }\end{array}$ & $\begin{array}{c}\text { Ca-content } \\
\text { ( } \text { mg g }^{-1} \\
\text { DW) }\end{array}$ & $\begin{array}{c}\text { Mg- } \\
\text { content } \\
\text { ( } \text { mg g-1 }^{-1} \\
\text { DW) }\end{array}$ & $\begin{array}{c}\text { Fe-content } \\
\left(\mathrm{mg} \mathrm{g}^{-1} \mathrm{DW}\right)\end{array}$ \\
\hline \multirow{4}{*}{ Sulfarina } & $\mathrm{CT}$ & $7,88^{c}$ & $21,67^{c}$ & $213,86^{c}$ & $51,48^{c}$ & $82,40^{b}$ & $0,14^{c}$ \\
\hline & $\mathrm{CN}$ & $8,29^{a}$ & $24,95^{\text {a }}$ & $223,88^{a}$ & $56,80^{\text {a }}$ & $85,80^{a}$ & $0,38^{\text {a }}$ \\
\hline & $\mathrm{CS}$ & 8,07 b & $22,81^{b}$ & 217,38 b & $53,38^{\mathrm{b}}$ & 82,94 b & $0,26^{\mathrm{b}}$ \\
\hline & ANOVA & $* * *$ & $* * *$ & $* * *$ & $* * *$ & $* *$ & $* * *$ \\
\hline \multirow{4}{*}{ Sanguigna } & $\mathrm{CT}$ & $6,86^{c}$ & $21,38^{c}$ & $216,60^{b}$ & $47,50^{c}$ & $73,78^{c}$ & $0,16^{b}$ \\
\hline & $\mathrm{CN}$ & $8,22^{\text {a }}$ & 26,87 a & $222,70^{a}$ & $53,64^{a}$ & $82,84^{a}$ & $0,26^{\mathrm{a}}$ \\
\hline & $\mathrm{CS}$ & $7,44^{b}$ & $23,50^{b}$ & $222,18^{a}$ & $50,34^{b}$ & $78,80^{b}$ & $0,17 \mathrm{~b}$ \\
\hline & ANOVA & $* * *$ & $* * *$ & $* * *$ & $* * *$ & $* * *$ & $* * *$ \\
\hline \multirow{3}{*}{ Muscaredda } & $\mathrm{CT}$ & $6,43^{c}$ & $17,58^{\mathrm{c}}$ & $209,28^{c}$ & $47,67 \mathrm{c}$ & $78,98^{c}$ & $0,13^{c}$ \\
\hline & $\mathrm{CN}$ & 7,59 a & 21,47 a & $217,16^{a}$ & 53,99 a & $86,20^{a}$ & $0,36^{\mathrm{a}}$ \\
\hline & $\mathrm{CS}$ & $6,94^{b}$ & 19,47 b & 213,52 b & $51,66^{b}$ & $83,02^{\text {b }}$ & $0,23 \mathrm{~b}$ \\
\hline
\end{tabular}




\begin{tabular}{|c|c|c|c|c|c|c|}
\hline ANOVA & $* * *$ & $* * *$ & $* * *$ & $* * *$ & $* * *$ & $* * *$ \\
\hline
\end{tabular}
significant differences according to Tukey's (HSD) multiple-range test $(\mathrm{P}=0.05)$. Legend: $(\mathrm{CT})$ control; $(\mathrm{CN})$ natural zeolite ; $(\mathrm{CS})$ sterilized zeolite

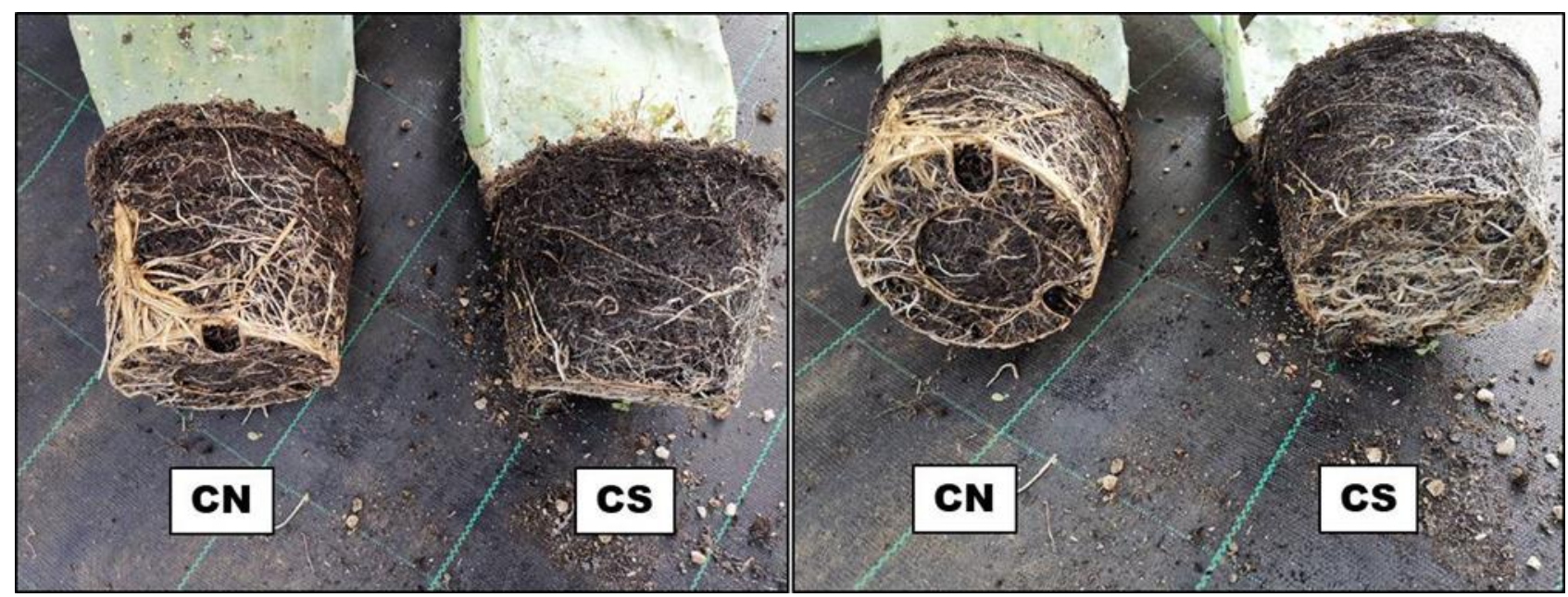

Figure 3 Effect of natural zeolite (CN) and sterilized zeolite (CS) on the roots growth of Opuntia ficus-indica cv 'Muscaredda'

\section{Discussion}

Zeolites possess a high cation exchange capacity, which determines the possibility that the internal cavities of their structure can accommodate different calcium, magnesium or sodium ions, and that these ions can be easily replaced by ammonium and potassium ions for which zeolites have a high affinity. For these characteristics are considered real molecular filters and are used in various sectors such as water purification, petrochemical industry, animal farming and as corroborating and biostimulant in horticulture and floriculture [16,17]. Zeolites, in fact, once introduced in growing substrates or in open field, can increase the quality of plants, retaining water and fertilizers and making them available when needed. In this experiment it was determined whether the capacities of zeolites are influenced by the microbial colonies that are present in the soil, which can with their activity increase the interactions between roots, zeolites and soil [18]. In this experiment it was determined whether the capacities of zeolites are influenced by the microbial colonies that are present in the soil, which can with their activity increase the interactions between roots, zeolites and soil. The microorganisms have the ability to lower the $\mathrm{pH}$ of the substrate and soil and can determine a solubilization of the mineral elements contained, which are more absorbed by plants $[19,20]$.

In this study, the theses treated with natural chabazite showed an improvement of all agronomic parameters analyzed on Opuntia ficus-indica plants, fruit characteristics and mineral content in the three cultivars Sulfarina, Sanguigna and Muscaredda. Natural chabazite gave better results than sterilized chabazite and untreated control, demonstrating that indeed the presence of the biotic component of zeolite plays a fundamental role in the interactions between zeolite and plant. This ensures an optimization of fertilizer use.

This exchange mechanism (zeolite-microorganism-plant) can occur either naturally with the microorganisms normally present in the soil or by adding beneficial microorganisms to the zeolite later, but the exchange of natural elements is significantly slower, because inoculated microorganisms need time to colonize the environment [15].

Zeolites can act as a "home" for microorganisms, as normally occurs in nature with clays. In fact, in conditions of water stress, the microorganisms take refuge inside the clay particles until the environmental conditions are appropriate again to colonize the soil [21]. Zeolites are able to actively interact with the organic components present in the soil and have the ability to make more available the mineral and nutritional components present within their crystal lattice, according to the needs of the plant [22,23]. In particular, the direct contact of zeolites with the root surface stimulates the production of mucilaginous substances (mucigel) by performing a lubricating action which can facilitate the absorption by the root of minerals and water. Evidence shows that zeolites once inserted into growth substrates can lead to an improvement in the quality aspects of the plants, particularly in this test there is also a significant increase in fruit quality and mineral content. This is probably due to increased reserves of energy and nutrients that the plant can allocate for different metabolic functions [24]. 


\section{Conclusion}

The test on Opuntia ficus-indica has shown that the use of zeolites can significantly improve plant growth. In particular the microbial component of zeolites has a particular importance to ensure the interactions that exist between these minerals and plant roots. The microorganisms in fact reduce the $\mathrm{pH}$ of the soil or substrate and the consequent emission of ions retained in the zeolites, which in this way are more available to plants. The plant having available at the time of need of minerals for ready use, suffers less stress, photosynthesizes and grows more and produces a greater number of flowers and fruits. All these aspects are very important for growers because the use of zeolites, especially natural chabazite, guarantees the possibility to reduce the amount of fertilizers in the substrates and to optimize irrigation while obtaining quality plants that grow better, produce more and suffer less.

\section{Compliance with ethical standards}

\section{Acknowledgments}

The research is part of the project "Micronaturale": innovative techniques with low environmental impact for the cultivation and defense of plants.

\section{Disclosure of conflict of interest}

The author declares no conflict of interest.

\section{References}

[1] Scheinvar L. Taxonomy of utilized Opuntias, in: Barbera G, P Inglese, E Pimienta-Barrios, (editors), Agroecology, cultivation and uses of cactus pear. FAO Plant Production and Protection Paper, Rome. (1995); 20-27.

[2] Le Houerou HN. Utilization of fodder trees and shrubs in the arid and semi-arid zones of West Asia and North Africa. Arid Soil Research and Rehabilitation. 2000; 14: 101-135.

[3] Estrada-Luna AA, Martínez-Hernández JDJ, Torres-Torres ME, Chablé-Moreno F. In vitro micropropagation of the ornamental prickly pear cactus Opuntia lanigera Salm-Dyck and effects of sprayed GA3 after transplantation to ex vitro conditions. Scientia Horticulturae. 2008; 117: 378-385.

[4] Medina EMD, Rodríguez EM, Romero CD. Chemical characterization of Opuntiadillenii and Opuntiaficus-indica fruits. Food Chemistry. 2007; 103: 38-45.

[5] Galati EM, Mondello MR, Giuffrida D, Dugo G, Miceli N, Pergolizzi S, Taviano MF. Chemical characterization and biological effects of sicilian Opuntiaficus-indica (L.) Mill. Fruit Juice: Antioxidant and Antiulcerogenic Activity. Journal of Agricultural and Food Chemistry. 2003; 51: 4903-4908.

[6] Piga A. Cactus Pear: A Fruit of Nutraceutical and Functional Importance. Journal of the Professional Association for Cactus Development. 2004; 9-22.

[7] Prisa D. Effect of chabazitic-zeolites and effective microorganisms on growth and chemical composition of Aloe barbadensis Miller and Aloe arborescens Miller. International Journal of Agricultural Research, Sustainability, and Food Sufficiency (IJARSFS). 2019; 6(01): 315-321.

[8] Prisa D. Italian chabazitic-zeolitite and Effective microorganisms for the qualitative improvement of olive trees. Atti del Convegno di Calci (PI) 2017 Atti Soc. Tosc. Sci. Nat., Mem., Supplemento. 2018; 125.

[9] Allen ER, Ming DW. Recent progress in the use of natural zeolites in agronomy and horticulture. In: Ming D.W. \& Mumpton F.A. (Eds.), Natural Zeolites '93: Occurrence, Properties, Use, ICNZ, Brockport, New York. 1995; 477490.

[10] Galli E, Passaglia E. Natural Zeolites In Environmental Engineering. In: H. Holzapfel (Ed.), Zeolites In Chemical Engineering, Verlag Processeng Engineering Gmbh, Vienna. 2011; 392-416.

[11] Prisa D. Rhizobacteria and zeolites for overcoming saline stress in the cultivation of succulent plants. The International Journal of Engineering and Science (IJES). 2019; 8(5): Series I 38-41.

[12] Gualtieri AF, Marchi E, Passaglia E. Zeolite content and cation exchange capacity of zeolite-rich rocks. Studies in Surface Science and Catalysis. 1999; 125: 707-713. 
[13] Prisa D. Zeolites as additives for the rooting of Camellia japonica and Proteaceae Juss. The International Journal of Engineering and Science (IJES). 2019; 8(5): Series I, 10-14.

[14] Mumpton FA. Natural Zeolites-A New Industrial Mineral Commodity." In: IVaturalZeolites: Occurrence, Properties, Use, L. B, Sand and F. A. Mumpton (eds.). 1978.

[15] Gualtieri AF. Study of NH4+ in the zeolite phillipsite by combined synchrotron powder diffraction and IR spectroscopy. Acta Cryst. 2000; B56: 584-593.

[16] Prisa D. Cultivation and cold stress protection in Crassula with zeolitites. The International Journal of Engineering and Science (IJES). 2019; 8(6): Series I, 29-34.

[17] Mackown CT, Tucker TC. Ammonium nitrogen movement in a coarse-textured soil amended with zeolite. Soil Science Society of America Journal. 1985; 49(2): 225-238.

[18] Prisa D. Rhizobacteria and zeolites for overcoming saline stress in the cultivation of succulent plants. The International Journal of Engineering and Science (IJES). 2019; 8(5): Series I, 38-41.

[19] Prisa D. Germination of Vegetable and Grassland species With Micronized chabazitic-Zeolites And Endophytic Fungi. IOSR Journal of Agriculture and Veterinary Science (IOSR-JAVS). 2019; 12(5): Ser. I, 32-37.

[20] Prisa D. Optimised fertilisation with zeolitites containing Plant Growth Promoting Rhizobacteria (PGPR) in Ranunculus asiaticus. GSC Biological and Pharmaceutical Sciences. 2000; 10(01): 096-102.

[21] Prisa D. Chabatitic Zeolites With Earthworm Humus Added To The Growing Media To Improve Germination and Growth of Horticultural Plants, International Journal of Scientific Research in Multidisciplinary Studies. 2000; 6(5): 24-31.

[22] Ando H, Mihara C. The fate of ammonium nitrogen applied to flooded rice as affected by zeolite addition. Soil Science and Plant Nutrition. 1996; 42(3): 531-538.

[23] Ferguson GA, Pepper IL, Kneebone WR. Ammonium retention in sand amended with clinoptilolite. Soil Science Society of American Journal. 1987; 51: 231-234.

[24] Prisa D. Particle films: chabazitic zeolites with added microorganisms in the protection and growth of tomato plants (Lycopersicon esculentum L.). GSC Advanced Research and Reviews. 2020; 4(2): 01-08.

\section{Author's short biography}

Dr. Domenico Prisa
Dr. Domenico Prisa is Doctor of Philosophy - PhD, Crop Science Production (S.Anna-School
of advances studies). Master of Science (MSc), Plant and Microbial Biotechnology (Pisa
University). He is currently researcher at Council for Agricultural Research and Economics
(CREA) - Landscaping Plants and Nursery Research Unit in Pescia (PT). Activities in
ornamental plants and horticulture, with particular reference to the study of
microorganisms and biostimulants on succulent plants and cacti. Speaker at several
national and international conferences in floriculture, sustainable agriculture, innovative
substrates and biostimulants, microbiology and beekeeping. His skills comprise
biotechnologies and innovative crop techniques.

